Department of Anatomy (Prof. T. Y. Yамамото), Tohoku University School of Medicine, Sendai, Japan

\title{
Ultrastructure and Function of the Granule-Containing Cells in the Anuran Sympathetic Ganglia
}

\author{
Hiroshi Watanabe
}

\begin{abstract}
Summary. In the sympathetic ganglia of various anuran species clusters of small granule-containing cells (GC cells) appeared more of ten in the 5th to 7 th paravertebral ganglia rather than in the 9th and 10th ganglia of the sympathetic chain. The GC cells were classified into four types according to the granular vesicle morphology. Types I, II and III cells probably acted as endocrine cells which secrete catecholamines into blood capillaries or extracellular spaces. Ty pe IV cells, however, resembled sympathetic ganglion cells. They seemed to be a special type of postganglionic adrenergic neuron rather than a type of interneuron. All these four cell types received cholinergic innervations.

Ganglion cells in the anuran sympathetic ganglia formed no synapses with the adrenergic elements or the GC cells. Hence, it was unlikely that s-IPSP was mediated by catecholamines released from GC cells. Serial section studies revealed that both B- and $\mathrm{C}$-neurons received only cholinergic innervation. A mechanism of s-IPSP production was discussed in correlation with the morphological findings.
\end{abstract}

Early pharmacological experiments suggested that catecholamines modulate transmission in the sympathetic ganglia (MARRAzZI, 1939; Bülbring, 1944; EcClEs and LiBET, 1961). Focusing on the physiological significance of catecholamines in the sympathetic ganglia, previous workers (BüLBRING, 1944; ECCLES and LIBET, 1961) suggested that chromaffin cells, which had already been reported in the sympathetic ganglia (SMIRnow, 1890; KoHN, 1903), might supply adrenaline to the synaptic transmission process.

Numerous morphological experiments primarily using mammalian sympathetic ganglia have been conducted to identify the adrenergic elements which would produce an inhibitory postsynaptic potential (s-IPSP) (GRILLO, 1966; SIEGRIST et al., 1968; Matthews and Raisman, 1969; as reviews Jacobowitz, 1970; Matthews, 1974; Gabella,1976; Williams et al., 1976). By electron microscopy, granule-containing cells (GC cells) are readily discernible in the sympathetic ganglia. They correspond to the small intensely fluorescent cells (SIF cells) seen in fluorescence microscope studies for catecholamines (Jасовоwitz, 1970, 1974; Matthews, 1974; Grillo et al., 1974; Gabella, 1976; Williams et al., 1976).

Previous authors noted the existence of various GC cells and assigned different functional significances to them: an interneuron function (Williams, 1967; Williams and PALAY, 1969; and others), an endocrine cell function (GRILlo, 1966; Siegrist et al., 1968; Matthews and Raisman, 1969; and others) or a chemoreceptor cell function (ERÄNKÖ and ERÄNKÖ, 1971; TAMARIND and Quilliam, 1971; see also GABELla, 1976).

Here, the fine structure of the GC cells in the anuran sympathetic ganglia was reviewed. The functional significance of these cells was also discussed in reference to electrophysiological studies on the transmission mechanism in the sympathetic ganglia (Nishi et al., 1967; Tosaka et al., 1968; Koketsu, 1969; Libet, 1970; Nishi, 1974). 


\section{Catecholamine-containing elements in light and fluorescence microscopy}

The GC cells have been observed in the sympathetic ganglia of a variety of anuran species (Fujimoto, 1967; Piezzi and Rodriguez Echandia, 1968; Honma, 1970a, b; Jacobowitz, 1970; Hill et al., 1975a; Watanabe and Burnstock, 1976b; Weight and WeItSEn, 1977). These cells stain densely with toluidine blue thereby facilitating easy identification. They are often located in close topographical relation to the blood vessels (Fujimoto, 1967; Hill et al., 1975a; Watanabe and Burnstock, 1976b), or are among the ganglion cells.

Fluorescent microscopic studies have revealed that clusters of SIF cells are present in the anuran sympathetic ganglia and that they correspond to the chromaffin cells of light microscopy and the GC cells of electron microscopy (HonMA, 1970a; Jacobowitz, 1970; Weitsen and Weight, 1973; Hill et al., 1975a; Weight and WeItsen, 1977). The SIF cells occur in variable number in all ganglia of the sympathetic chain. They are more numerous in the 5th, 6th and 7 th ganglia than in the 9th and 10th ganglia (Hill et al., 1975a). Weight and Weitsen (1977) demonstrated that small clusters of SIF cells are sparsely distributed in the 9th and 10th ganglia and that the SIF cells show positive chromaffin reaction in the bullfrog, Rana catesbeiana. PICK (1963) also suggested the presence of GC cells in the frog, Rana pipiens, sympathetic ganglia, but he could not demonstrate the presence of any chromaffin cell.

NoRBERG and SJÖQVIST (1966) proposed that the inhibitory mechanism in the mammalian sympathetic ganglia might depend upon catecholamines released from fluorescent basket-like terminals (see also Jасовоwiтz, 1970, 1974). Some of these fluorescent fibers may represent processes derived from the SIF cells, and others may represent adrenergic endings which originated from axonic or dendritic collaterals of postganglionic neurons (GRILlo, 1966; WatanABE, 1971; YоKоTA and Yamauchi, 1974; as reviews Jacobowitz, 1970, 1974; Matthews, 1974; Gabella, 1976; Williams et al., 1976). In the mammalian sympathetic ganglia, a direct synaptic contact between adrenergic presynaptic elements and postsynaptic neurons has been demonstrated by electron microscopic studies (see reviews of MatThEws, 1974; Gabella, 1976; Williams et al., 1976).

JACOBOWITZ (1970) noted in his fluorescence microscopic study that adrenergic interneurons are present in the bullfrog sympathetic ganglia. This is the only study in the anuran species that suggests the innervation of ganglion cells by interneurons. In the frog, Rana temporaria, no fluorescent adrenergic nerves were found terminating on the ganglion cell bodies or axons in the paravertebral sympathetic chain from the 7th to 10th ganglia (NoRBERG and McIsAac, 1967). Similar observations of the absence of adrenergic endings have been reported in the 9 th and 10th sympathetic ganglia of the toad, Bufo vulgaris japonica (Honma, 1970a), the bullfrog, Rana catesbeiana (WEIGHT and WeITSEN, 1977) and the sympathetic chains of a frog, Limnodynastes dumerili (HiLl et al., 1975a).

\section{Fine structure of the GC cells}

The GC cells are polyhedral in shape, about 10 to $20 \mu \mathrm{m}$ in diameter (Fig. 1). The most characteristic components of the GC cell are electron dense granular vesicles of various sizes; 100-700 $\mathrm{nm}$ in the frog, Limnodynastes dumerili (HILL et al., 1975a) 


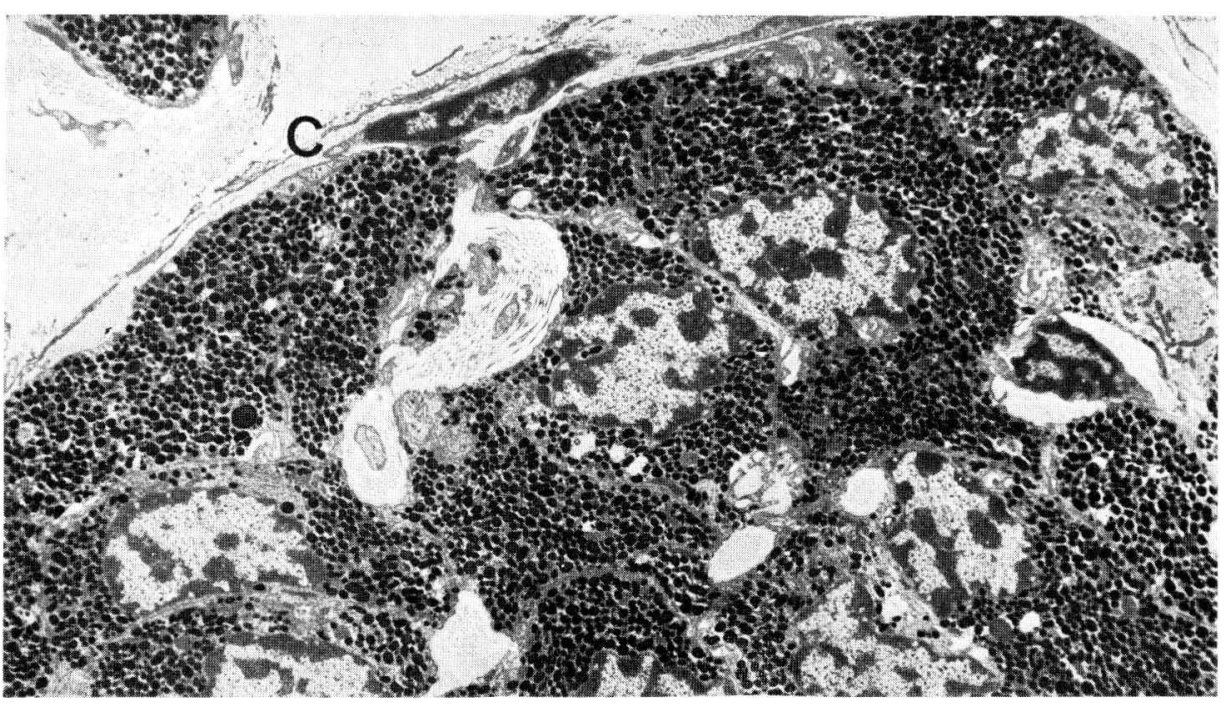

All micrographs are taken from the sympathetic ganglion of the frog, Limnodynastes dumerili.

Fig. 1. A thin connective tissue capsule $(C)$ enclosing a cluster of GC cells (Type I). Densely packed large granular vesicles are seen in the cytoplasm of the GC cell. $\quad \times 4,000$

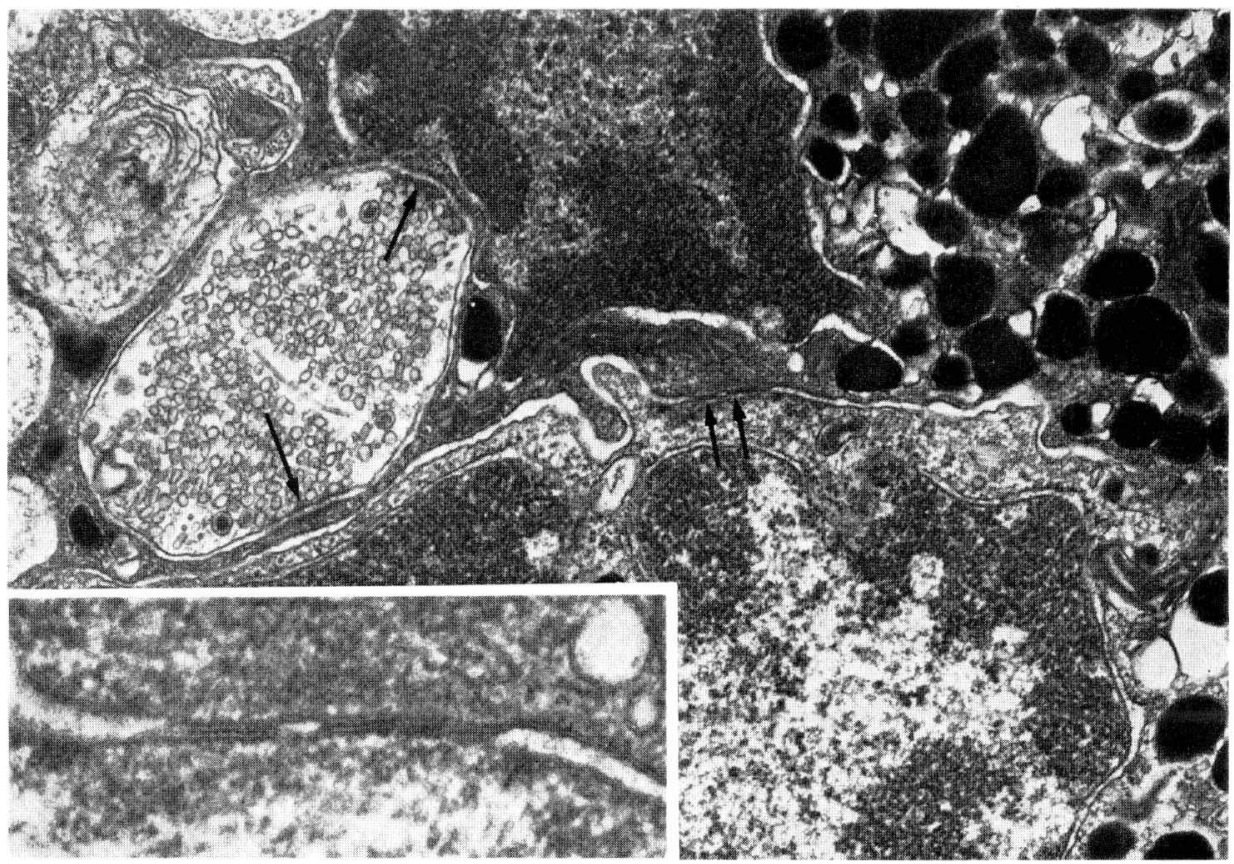

Fig. 2. Adjacent GC cells. A presynaptic nerve ending, apparently cholinergic, forms synaptic specializations (arrows) on the GC cell. $\times 25,000$. Inset. A larger magnfication of the double arrowed area. Note small gap junctions. $\times 100,000$ 
and $200-600 \mathrm{~nm}$ in the toad (Fujimoto, 1967). They are larger than those of the mammalian extra-adrenal chromaffin cells (about 100-300 nm, see GABELlA, 1976). Mitochondria, granular endoplasmic reticulum and Golgi apparatus are also seen in the cytoplasm. Adjacent GC cells are frequently in close contact; intervention of the satellite cell sheath does not occur. Here, the apposed plasma membranes are separated only by an extracellular space of about 15 to $20 \mathrm{~nm}$ (Hill et al., 1975a). Small symmetric membrane thickenings (fascia adherens-like junctions) and presumable gap junctions are formed between these adjacent cells (Fig. 2). A part of the GC cell surface lacks the satellite cell sheath and is covered only with a thin basal lamina. Cultured GC cells show similar fine structural features (Hill et al., 1975b).

GC cell types: The ultrastructure of the GC cells in the pararenal sympathetic ganglion of the toad is similar to that of the noradrenaline-storing cells of the snake adrenal (Piezzi and Rodriguez Echandia, 1968). It seems that adrenaline is the chemical transmitter released from the bullfrog sympathetic postganglionic neurons (Azuma et al., 1965), although the sympathetic chains in the bullfrog contain 3 times

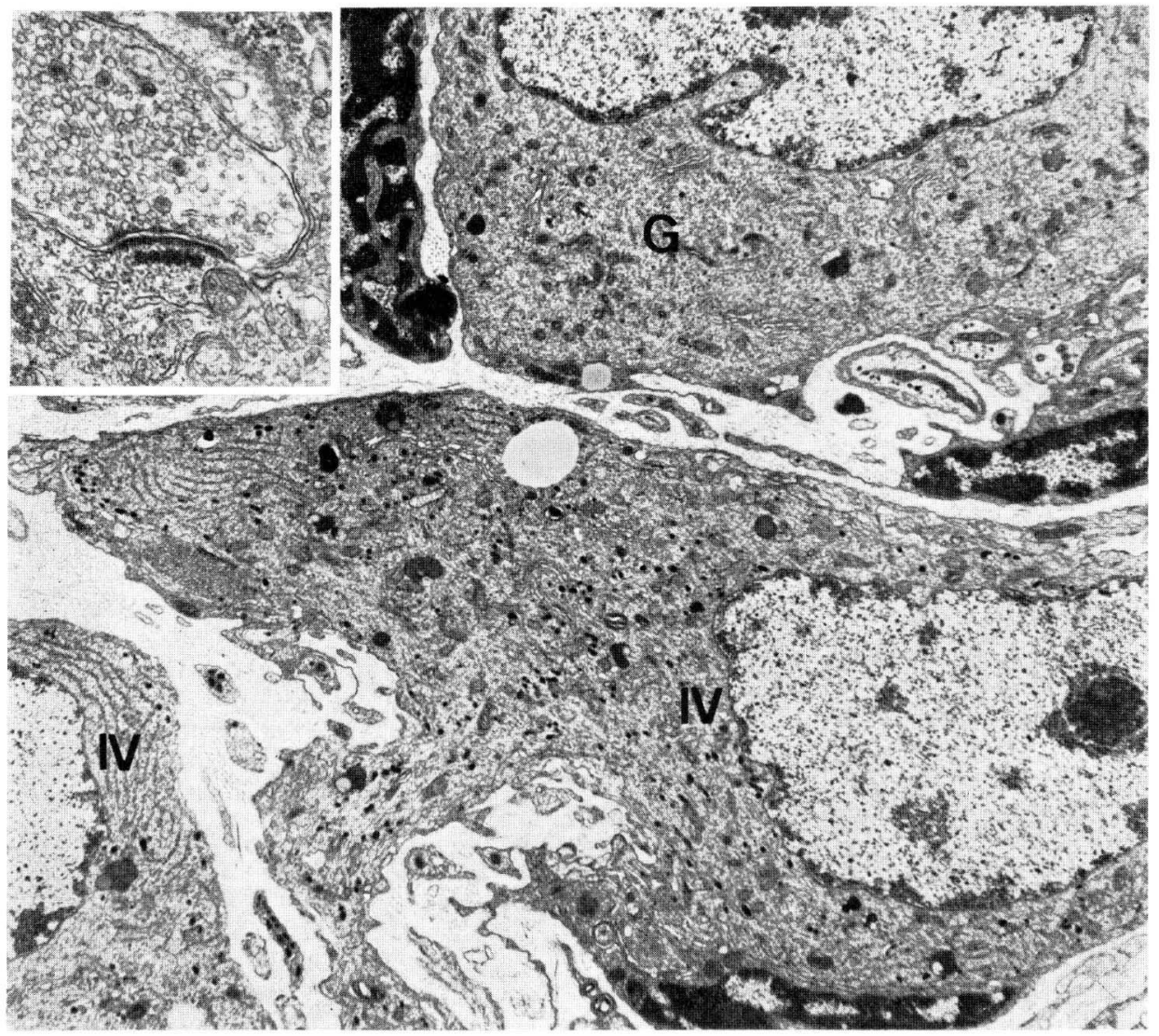

Fig. 3. A picture showing small sympathetic ganglion cell $(G)$ (C-neuron) and special type of GC cells (Type IV) containing many electron-dense granular vesicles. The Type IV cell forms an axon-like process. $\times 7,500$. Inset shows a postsynaptic bar which is seen exclusively in the small ganglion cells. $\times 24,000$ 
more noradrenaline $(10.09 \mu \mathrm{g} / \mathrm{g}$ wet tissue) than adrenaline $(2.94 \mu \mathrm{g} / \mathrm{g})$. This biochemical observation suggests that the majority of GC cells in the bullfrog sympathetic ganglion contain noradrenaline (Azuma et al., 1965).

Four types of GC cells have been distinguished in the frog sympathetic ganglia, Limnodynastes dumerili (HILl et al., 1975a), based on the morphology of their vesicular components. Type I cells are the most numerous and contain large electron dense vesicles $(60-700 \mathrm{~nm})$ with structures similar to that of the noradrenaline type vesicles in the adrenomedullary cells. Type II cells contain large vesicles $(60-700 \mathrm{~nm})$ filled with a less electron dense material as compared to Type I cells. Comparing the electron microscopic features, the vesicles resemble those of the adrenaline-storing cells in the adrenal medulla. Type III cells contain smaller vesicles $(100-300 \mathrm{~nm})$ which are incompletely filled with an electron dense material. HILL and her co-workers (1975a) proposed that this type represented a transitional functional phase of either Type I or Type II.

Type IV cells are clearly different from the other three cell types with respect to the size and population of the granular vesicles $(100-150 \mathrm{~nm})$ (Fig. 1, 3). The distribution of the granular vesicles in the Type IV cell is sparse (Hill et al., 1975a; WAtANABE and Burnstock, 1976b). Because of the high density of the granules, it is likely that they contain noradrenaline or dopamine rather than adrenaline (HILL et al., 1975a; WATANABE and BuRNstock, 1976b).

Innervation of the GC cells: There have been many controversial reports concerning the innervation of GC cells. Piezzi and Rodriguez Echandia (1968) reported that no nerve fibers come into direct contact with the plasmalemma of GC cell in the toad, Bufo arenarum. In the bullfrog, the GC cells in the 9th and 10th paravertebral sympathetic ganglia also receive no synapse (WEITSEN and WeIGHT, 1973; WeIGHT and Weitsen, 1977). However, in the toad, Bufo vulgaris japonicus, Fujimoto (1967) reported that synaptic junctions between nerve endings and GC cells are formed. And Uchizono and OHSAwa (1973) reported the presence of GC cells innervated by cholinergic axons in the toad and a frog sympathetic ganglia.

All four types of GC cells present in the frog have been confirmed to receive presynaptic nerve endings which are probably cholinergic in nature (Fig. 2) (Hill et al., 1975a; W AtAnABE and Burnstock, 1976b). Serial-section studies have revealed that most, if not all, of the Types I. II and III cells possessed 1 to 6 postsynaptic membrane specializations. Five Type IV cells (A, $15 \times 14 \times 12 \mu \mathrm{m} ; \mathrm{B}, 15 \times 10 \times 18 \mu \mathrm{m} ; \mathrm{C}, 19 \times 14$ $\times 7 \mu \mathrm{m} ; \mathrm{D}, 15 \times 10 \times 22 \mu \mathrm{m} ; \mathrm{E}, 12 \times 10 \times 24 \mu \mathrm{m}$ in diameter) were examined by complete serial sectioning. Four of them possessed 6 to 8 postsynaptic membrane specializations on the surface of each cell soma. The remaining cell had no axo-somatic synapse but had several synapses on its axon-like process.

Contact between GC cells and ganglion cells: Our serial-section study revealed that none of the four types of GC cells comes into close contact with the ganglion cells (WATANABE and Burnstock, 1976a, b, 1977). This result agrees well with the earlier fluorescent microscopic observations on the anuran sympathetic ganglia (Norberg and McIsaAc, 1967; Honma, 1970a; Weitsen and Weight, 1973; Hill et al., 1975a). Cultured GC cells are frequently associated with sympathetic ganglion cells, but no synapse formation occurs between GC cells and ganglion cells (HILl et al., 1975b). Weitsen and Weight $(1973,1977)$ have noted that the GC cells in the bull- 
frog paravertebral 9th and 10th sympathetic ganglia do not emanate synapses onto any other cell (see also Weight and WEITSEN, 1977).

Adrenergic innervation of ganglion cells: Previous workers assumed that the sympathetic ganglion cells of toads and frogs received adrenergic nerve endings (Uchizono and Ohsawa, 1973; Piezzi and Rodriguez Echandia, 1968), but none of them produced unequivocal structural evidence for this assumption. Only one type of nerve ending, presumably cholinergic, was reported in the toad sympathetic ganglia (Nishi et al., 1967). Recent thin serial section studies have indicated that in the frog sympathetic ganglia, adrenergic nerve fibers do not form any synaptic contact with the ganglion cells (W Atanabe and Burnstock, 1976a, b, 1977). Weitsen and WEIGHT (1977) also confirmed that adrenergic endings containing small granular vesicles are not found on the ganglion cells after incubation with $\alpha$-methyl-noradrenaline and potassium permanganate fixation.

Relationship of GC cells to the blood vessels: Several physiological studies suggested that in the anuran sympathetic ganglia, as in the mammalian ganglia, the synaptic process for s-IPSP includes the release of a second transmitter, catecholamine, from intraganglionic interneurons (chromaffin or SIF cells) (LiBET, 1970; Nakamura and Koketsu, 1972; Libet and Kobayashi, 1974). However, in morphological studies, synaptic contact of the GC cells to the neurons has not yet been found (Hill et al., 1975a; Watanabe and Burnstock, 1976a, b, 1977; Weight and Weitsen, 1977; Weitsen and Weight, 1977). Moreover, the distance between the GC cell and sympathetic neuron is too large to account for the delay in the generation of s-IPSP

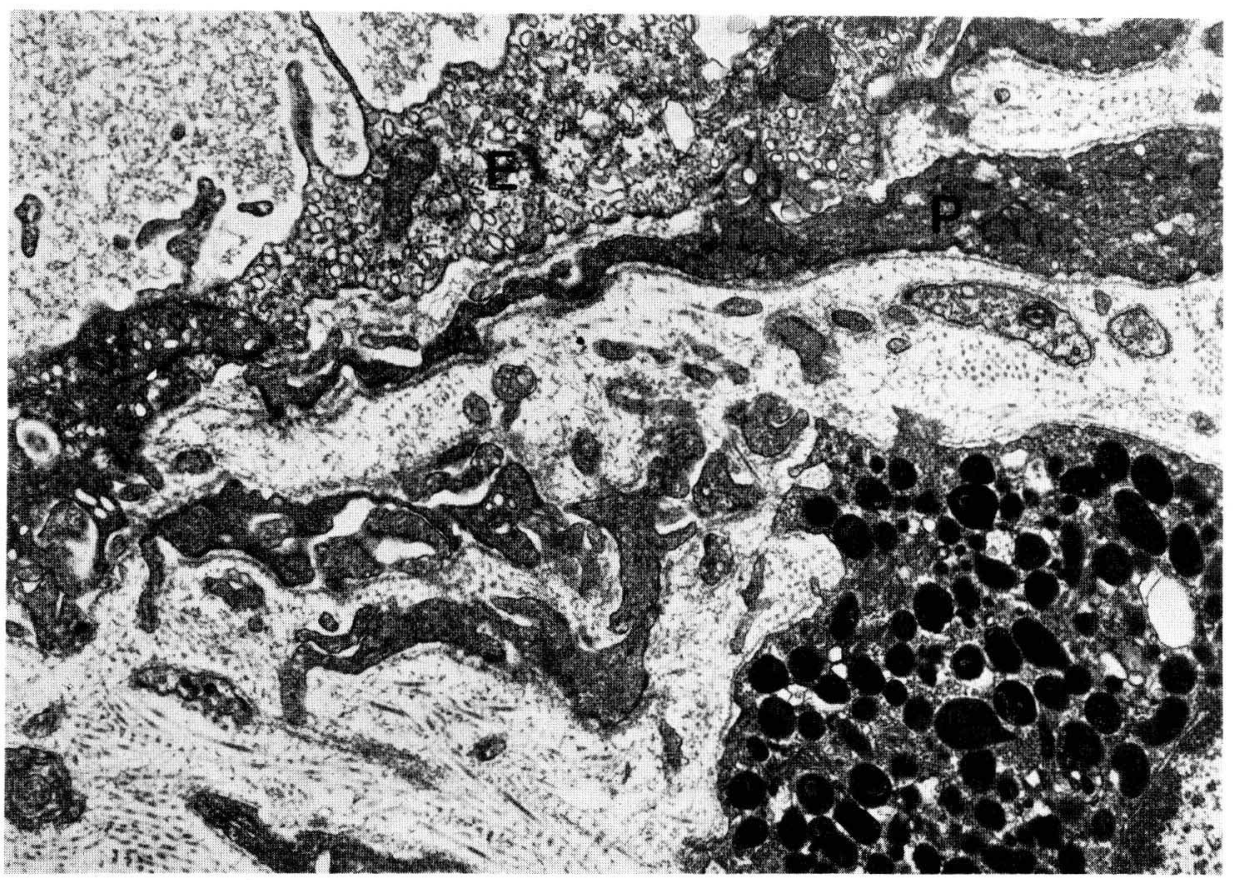

Fig. 4. A GC cell situated close to a continuous capillary. E endothelium of the capillary, $P$ pericytes. $\times 13,000$ 
(see Libet, 1970; WatAnABe and Burnstock, 1976b).

The possibility that the GC cells (Types I, II and III) may function as endocrine cells like those in the adrenal gland (Fujimoto, 1967; Hill et al., 1975a; Weight and WeItSEN, 1977) is supported by its intimate topographical relationship to the blood vessels (Fig. 4). However, in the type IV cells, close topographical relationship is not found between the blood vessels and the cell bodies/processes.

Type IV cell-A special type of GC cells: Types I, II and III cells resemble adrenomedullary cells (PIEzzi, 1967; Weight and Weitsen, 1977), as well as the GC cells in the sympathetic ganglia in various anuran species (Fujimoto, 1967; PIEzzi and Rodriguez Echandia, 1968; Weight and Weitsen, 1977); Type IV cells have so far been found only in a frog, Limnodynastes dumerili (Hill et al., 1975a; W ATANABE and Burnstock, 1976b). Thus the functional role of the Type IV cells remains to be elucidated.

The Type IV cells are isolated from neighbouring cells and are almost completely enclosed by a satellite cell sheath (Fig. 3). Each cell possesses an axon-like, long process which usually becomes incorporated into a nerve bundle; no other types of GC cell extend such a long process. Some short dendrite-like processes are also seen. The axon-like processes form neither efferent synapses on the principal neurons nor come into close relation with blood vessels within the sympathetic ganglion (WATANABE and BuRNSTOck, 1976a, b, 1977). The perikarya of Type IV cells contain well organized granular endoplasmic reticulum, dispersed Golgi apparatuses and many mitochondria as do the principal neurons.

The size of the Type IV cell is about 10 to $20 \mu \mathrm{m}$ in diameter; this is in the small ganglion cell or C-neuron range (Nishi et al., 1967; Honma, 1970b). They, however, can be distinguished from $\mathrm{C}$-neurons by the presence of numerous dense granular vesicles and by the absence of postsynaptic apparatuses (postsynaptic bars) characteristic of the C-neurons (Fig. 3). C-neurons receive dense innervations; 15 to 42 postsynaptic membrane specializations are formed for each cell (WATANABE and Burnstock, 1977). These findings suggest that Type IV cells are not interneurons or neurosecretory cells, but are a type of adrenergic sympathetic neuron with a long axon which are under the control of cholinergic endings (Hill et al., 1975a; W ATANABE and BuRnstock, 1976b).

\section{A morphological view on the mechanism of s-IPSP production}

From all the morphological observations so far reported, it is highly probable that in the anuran sympathetic ganglia s-IPSP is generated by the direct action of ACh released from presynaptic endings not by catecholamine action (WEIGHT and PAdjen, 1973a, b; WeItsen and Weight, 1973, 1977). It is also noteworthy that electrophysiological data on the s-IPSP have been obtained mainly from the two most caudal sympathetic ganglia, the 9th and 10th, which contain few GC or SIF cells (Weitsen and Weight, 1973; Hill et al., 1975a; Weight and Weitsen, 1977). The view that s-IPSP in the anuran sympathetic ganglion is mediated by adrenergic elements has no morphological basis at present.

The anuran sympathetic ganglion contains two types of neurons: B-neurons (30-35 $\mu \mathrm{m}$ in diameter) and C-neurons (about $20 \mu \mathrm{m}$ ) (Nishi et al., 1967; HonmA, 1970b; WATANABE and BuRnstock, 1977). Several physiologists have claimed that s-EPSP occurs in the B-neuron (TosAKA et al., 1968; LIBET, 1970) and s-IPSP in the C-neuron 
(Tosaka et al., 1968; Weight and PAdjen, 1973a, b). Morphologically, these two types of neuron are equipped with distinctive postsynaptic apparatuses: "junctional subsurface organs" in the B-neuron and "postsynaptic bars" in the C-neuron (W ATANABE and BuRnstock, 1977). The junctional subsurface organs are highly flattened subsurface cisterns often accompanied by endoplasmic reticulum and/or mitochondria (for detailed description on these apparatuses see WATANABE and BuRnstock, 1976a, 1977). The postsynaptic bars are assumably involved in the generation of s-IPSP, while the junctional subsurface organs, in the generation of s-EPSP (W ATANABE and BuRnstock, 1976b, 1977).

\section{両生類交感神経節内の果粒含有細胞の微細構造と役割}

$$
\text { 渡辺皓 }
$$

両生類交感神経節内には，多数の果粒含有細胞 (GC 細胞) の 様々な大きさの集団があ る. GC 細胞は第 5 から第 7 交感神経節の範囲に特に多く, 第 9 および第 10 交感神経節で は少ない. カエルの交感神経節内で分類された I, II および而型の GC 細胞の 主な機能 は，カテュールアミンの血流中への分泌であろう．特殊な GC 細胞として $\mathrm{N}$ 型が分類され たが，これは交感神経節細胞に類似した形態を示す. 第 $N$ 型の GC 細胞は内分泌や介在神 経ではなく，アドレナリン作働性の交感神経節後細胞の一種と思われる. GC 細胞は，二 リン作動性神経の支配を受ける。

両生類の交感神経節では，GC 細胞とその突起 およびアドレナリン作動性神経線維と, 交感神経節細胞との間の シナプス結合の記載はない. 連続切片による観察でも, カエル交 感神経節の $\mathrm{B}=ュ$ ニンおよび $\mathrm{C}$ 二ューロンは, ともにコリン作動性終末としての特 徵をもつ一種類の節前終末を受ける.

これらの形態学的所見は, 両生類交感神経節における抑制性シナプス電位の発生にカテ コールアミンが関与すると考えるよりも，これがアセチルコリンの直接作用によるものと の仮説に好都合だが，この点を最近の連続切片観察による結果と合わせて考察した。

\section{References}

Azuma, T., A. Binia and M. B. Visscher: Adrenergic mechanisms in the bullfrog and turtle. Amer. J. Physiol., 209: 1287-1294 (1965).

Bülbring, E.: The action of adrenaline on transmission in the superior cervical ganglion. J. Physiol. (Lond.) 103: 55-67 (1944).

Eccles, R. M. and B. L. Libet: Origin and blockade of the synaptic responses of curarized sympathetic ganglia. J. Physiol. (Lond.) 157: 484-503 (1961).

Eränkö, 0. and L. Eränkö: Small, intensely fluorescent granule-containing cells in the sympathetic ganglion of the rat. Prog. Brain Res. 34: 39-51 (1971).

Fujimoto, S.: Some observations on the fine structure of the sympathetic ganglion of the toad, Bufo vulgaris japonicus. Arch. histol. jap. 28: 313-335 (1967). 
Gabella, G.: Structure of the autonomic nervous system. Chapman and Hall, London, 1976.

Grillo, M. A. : Electron microscopy of sympathetic tissues. Pharmacol. Rev. 18: 387-399 (1966).

Grillo, M. A., L. Jacobs and J. H. Comroe, Jr.: A combined fluorescence histochemical and electron micoscopic method for studying special monoamine-containing cells (SIF cells). J. comp. Neurol. 153: 1-14 (1974).

Hill, C. E., H. Watanabe and G. Burnstock : Distribution and morphology of amphibian extraadrenal chromaffin tissue. Cell Tiss. Res. 160: 371-387 (1975a).

Hill, C. E., M. Hoult and G. Burnstock : Extra-adrenal chromaffin cells grown in tissue culture. Cell Tiss. Res. 161: 103-117 (1975b).

Honma, S.: Histochemical demonstration of catecholamines in the toad sympathetic ganglia. Jap. J. Physiol. 20: 186-197 (1970a).

- Functional differentiation in $\mathrm{sB}$ and $\mathrm{sC}$ neurons of toad sympathetic ganglia. Jap. J. Physiol. 20: 281-295 (1970b).

Jacobowitz, D.: Catecholamine fluorescence studies of adrenergic neurons and chromaffin cells in sympathetic ganglia. Fed. Proc. 29: 1929-1944 (1970).

- : The peripheral autonomic system. In: (ed. by) J. I. Hubbard: The peripheral nervous system. Plenum Press, New York-London, 1974. (p. 87-110).

Kohn, A.: Die Paraganglien. Arch. microsk. Anat. 62: 263-365 (1903).

Koketsu, K.: Cholinergic synaptic potentials and the underlying ionic mechanisms. Fed. Proc. 28: 101-112 (1969).

Libet, B.: Generation of slow inhibitory and exitatory postsynaptic potentials. Fed. Proc. 29: 1945-1956 (1970).

Libet, B. and H. Kobayashi : Adrenergic mediation of slow inhibitory postsynaptic potential in sympathetic ganglia of the frog. J. Neurophysiol. 37: 805-814 (1974).

Marrazzi, A. S.: Adrenergic inhibition at sympathetic synapses. Amer. J. Physiol. 127: 738-744 (1939).

Matthews, M. R.: Ultrastructure of ganglionic junctions. In: (ed. by) J. I. Hubbard: The peripheral nervous system Plenum Press, New York-London, 1974. (p. 111-150).

Matthews, M. R. and G. Raisman: The ultrastructure and somatic efferent synapses of small granule-containing cells in the superior cervical ganglion. J. Anat. 105: 255-282 (1969).

Nakamura, M. and K. Koketsu : The effect of adrenaline on sympathetic ganglion cells of bullfrogs. Life Sci. 11: 1165-1173 (1972).

Nishi, S. : Ganglionic transmission. In: (ed. by) J. I. Hubbard: The peripheral nervous system. Plenum Press, New York-London, 1974. (p. 225-256).

Nishi, S., H. Soeda and K. Koketsu : Release of acetylcholine from sympathetic preganglionic nerve terminals. J. Neurophysiol. 30: 114-134 (1967).

Norberg, K.-A. and R. J. McIsaac: Cellular location of adrenergic amines in frog sympathetic ganglia. Experientia 23: 1052 (1967).

Norberg, K.-A. and F. Sjöqvist: New possibilities for adrenergic modulation of ganglionic transmission. Pharmacol. Rev. 18: 743-751 (1966).

Pick, J. : The submicroscopic organization of the sympathetic ganglion in the frog (Rana pipiens). J. comp. Neurol. 120: 409-462 (1963).

Piezzi, R. S. : Chromaffin tissue in the adrenal gland of the toad, Bufo arenarum Hensel. Gen. comp. Endocrinol. 9: 143-153 (1967).

Piezzi, R. S. and E. L. Rodriguez Echandia: Studies on the pararenal ganglion of the toad Bufo arenarum Hensel. I. Its normal fine structure and histochemical characteristics. Z. Zellforsch. 88: 180-186 (1968).

Siegrist, G., M. Dolivo, Y. Dunant, C. Foroglou-Kerameus, Fr. de Ribaupierre and Ch. Rouiller: Ultrastructure and function of the chromaffin cells in the superior cervical ganglion of the rat. J. Ultrastr. Res. 25: 361-407 (1968).

Smirnow, A.: Die Struktur der Nervenzellen im Sympathicus der Amphibien. Arch. microsk, 
Anat. 35: 407-424 (1890).

Tamarind, D. L. and J. P. Quilliam : Synaptic organisation and other ultrastructural features of the superior cervical ganglion of the rat, kitten and rabbit. Micron 2: 204-234 (1971).

Tosaka, T., S. Chichibu and B. Libet: Intracellular analysis of slow inhibitory and exitatory postsynaptic potentials in sympathetic ganglia of the frog J. Neurophysiol. 31: 396-409 (1968).

Uchizono, K. and K. Ohsawa : Morpho-physiological consideration on synaptic transmission in the amphibian sympathetic ganglion. Acta physiol. pol. 24: 205-214 (1973).

Watanabe, H.: Adrenergic nerve elements in the hypogastric ganglion of the guinea pig. Amer. J. Anat. 130: 305-330 (1971).

Watanabe, H. and G. Burnstock : Junctional subsurface organs in frog sympathetic ganglion cells. J. Neurocytol. 5: 125-136 (1976a). - : A special type of small granule-containing cell in the abdominal para aortic region of the frog. J. Neurocytol. 5: 465-478 (1976b).

- : Postsynaptic specialisations at excitatory and inhibitory cholinergic synapses. J. Neurocytol. (1977, in press).

Weight, F. F. and A. Padjen : Solw synaptic inhibition: evidence for synaptic inactivation of sodium conductance in sympathetic ganglion cells. Brain Res. 55: 219-224 (1973a).

- : Acetylcholine and slow synaptic inhibition in frog sympathetic ganglion cells. Brain Res. 55: 225-228 (1973b).

Weight. F. F. and H. A. Weitsen : Identification of small intensely fluorescent (SIF) cells as chromaffin cells in bullfrog sympathetic ganglia. Brain Res. 128: 213-226 (1977).

Weitsen, H. A. and F. F. Weight : Chromaffin cells in the frog sympathetic ganglion: morphology not consistent with role in generation of synaptic potentials. Anat. Rec. 175: 467 (1973). - : Synaptic innervation of sympathetic ganglion cells in the bullfrog. Brain Res. 128: 197-211 (1977).

Williams, T. H.: Electron microscopic evidence for an autonomic interneuron. Nature 214: 309310 (1967).

Williams, T. H., A. C. Black, Jr., T. Chiba and J. Jew : Interneurons/SIF cells in sympathetic ganglia of various mammals. In: (ed. by) R. E. Coupland and T. Fujita: Chromaffin, enterochromaffin and related cells. Elsevier, Amsterdam-New York, 1976. (p. 95-116).

Williams, T. H. and S. L. Palay : Ultrastructure of the small neurons in the superior cervical ganglion. Brain Res. 15: 17-34 (1969).

Yokota, R. and A. Yamauchi : Ultrastructure of the mouse superior cervical ganglion, with particular reference to the pre- and postganglionic elements covering the soma of its principal neurons. Amer. J. Anat. 140: 281-298 (1974).

\author{
渡辺皓 \\ 于980 仙台市星陵町 $2-1$ \\ 東北大学医学部 \\ 第二解剖学教室
}

Dr. Hiroshi Watanabe

Department of Anatomy

Tohoku University School of Medicine

Sendai, 980 Japan 